\title{
Alessandro Ferrara: The Democratic Horizon. Hyperpluralism and the Renewal of Political Liberalism.
}

Cambridge U.P. 2014, 254 p.

\begin{abstract}
Democracy is a personal way of individual life ... it signifies the possession and continual use of certain attitudes, forming personal character and determining de-sire and purpose in all the relations of life. Instead of thinking of our own disposetions and habits as accommodated to certain institutions we have to learn to think of the latter as expressions, projections and extensions of habitually dominant per-sonal attitudes.
\end{abstract}

John Dewey, "Creative Democracy - The Task before Us"

First of all, I would like to say that I highly praise Alessandro Ferrara's work and his efforts exhorted in research. It is also quite necessary to mention that Alessandro Ferrara's book, as a whole, is certainly one of the important works in the area of social and political science on present days. In my view this work delivers a broad analysis with a very method-logically conceived review on the main theoretical aspects, such as: democracy and pluralism, including modern ideas for renewal of political liberalism and so on. Among the other focuses, the author aims at the possible outcomes of multiculturalism in form of a negation or a completion of liberalism which bring about another way of understanding democracy, i.e. as openness. This point of view, then, allows Alessandro Ferrara to move beyond the nation towards the so called global governance and thus actually engage further with all that is related to deliberative democracy.

This book, beyond any doubt, delivers such an insight to the theme that no other one than a writer of high erudition can hope for in order to produce this level of outcome, and thus the work has its impressive value both for Alessandro Ferrara himself as well as for the readers of the subject, too. In addition, just to complete my expression of appreciation towards this book with its professional impact on progressing of the subject in general, I must frankly admit that the way, the topic is approached in the book, generates an inspiration and at the same time I am sure that one's horizons will be expanded as well, at least in my view, anyway.

However, I am afraid that there are also other angles and ways of comprehension which I would like to talk about. So, if I may continue my comment further, then it is reminding me that the author explains right at the beginning that democracy, establishing itself as the only legitimate form of government, faces actu- 
ally unprecedented challenge worldwide. The work itself is, more or less, the author's presentation of upholding modern ideals of political liberalism. The author's intent to analyse internal resources at democracy's disposal for resisting inegalitarian and oligarchic pressures in order to remain faithful to the democracy's main principles in future, especially the one of self-governance (Ferrara $2014,2-3$ ), is indeed a meritorious decision. Now, I actually wonder whether the success of such intention is not rather dubious, as in its core, it is in fact avoiding, maybe even prohibiting, any meaningful attempt not only to identify the primary causes of inegalitarian and oligarchic pressures, but also to prevent further widening of any major differences as well as injustice in societies in general, as an outcome of democracy's resources for any real resistance to such trends (Ferrara 2014, 210-211).

Alessandro Ferrara proceeds that democracy as such can become truly global provided that it is no longer a synonym to Westernisation (Ferrara 2014, 3), but rather, if it opens up to diversity and acquires also other forms, which are being offered in the present world. It might be also useful to realize that these requirements are actually attributes of cosmopolitan conception of the world. Further on, one can assume though that even the modern ideals of the political liberalism may not be enough to save liberalism as such from becoming eventually a blockage-like conservative factor on behalf of preserving the historically generated status quo in social relations in general which is, as a matter of fact, a gradually modified system of the original slavery and totalitarianism of the old past. (Ferrara 2014, 87)

Notwithstanding, it is historically obvious that democracy as such needs a society to succeed, i.e. a society which does not have a lack of provisions or scarcity in any major area of societal life, which actually means that democracy has to be basically ready for applying the principles of liberty on the ground of equality, and at the same time also the principles of justice on the ground of social goods like hypergoods (Ferrara 2014, 156). And then, this means that democracy as a political system is not suitable for any (i.e. random) society existing in the world, because without a noble (i.e. decent and ethical) approach towards other parts and categories of societies (like minorities), it is as a matter of fact almost impossible to establish a stable (i.e. sustainable) society. This explanation derives from practical analysis of the present day world, which is still fixed (maybe even blocked); with the global (i.e. post-colonial) neo-liberalism that is still upholding already rather atavistic national sovereignty. Consequently, sovereignty is in fact understood on the one hand as a domain of political power, and on the other as a sort of protection against various modern forms of semi-colonial influence (Ferrara 2014, 183).

It ought to be also mentioned that in connection with the Progressive Realists' theories it is actually indicative of the direction of political development in the 
international affairs, that in the present world the historical orientation should be aimed towards the multilateral, globally representative, governance (i.e. essentially on the basis of cosmopolitan universalism). Presumably, it should deliver a good chance to access maybe the only sustainable path (towards future) of civilizational progress on this planet (Ferrara 2014, 30).

Nevertheless, the current contextual situation in the area of the social and political affairs with the critical trends in action at the background has also been caused by the so called "cast-system" of social as well as societal (i.e. congenital) inequalities which have still been maintained in the relations of this world. The higher (i.e. ruling) classes have been historically utilising the systemic social technic of maintaining grasp on power based on the principal of inequalities as one of the essential instruments of class domination. It is quite obvious especially in the areas of economic and political capital, which still enables the ruling classes to adjust to the modern times, thus preserve the traditional dominion for the so called popular celebrities and official dignitaries as well as other types of modernising capitalists in the present world of ours, though mainly on the basis of the "good old" systemic exploitation. All this described constitutes the elementary pillars of traditions for social hierarchy that are fixing the immobility between the social classes which are, as a whole, historical heritage of conserving social exploitation of "a man by a man", i.e. the subject \& object paradigm (Suša 2010, 194-196).

After all, provided that the modern political proclamations about equality on the level of cultures as well as on the intersubjective level of individual actors within societies (i.e. the basic human and political rights) have been meant seriously, then it is necessary to stop preserving the social phenomenon of elitist class system. In spite of the fact that it is officially, i.e. in a formal way, admitted only in case of monarchies, it is still a reality for any society in our world at the beginning of the $21^{\text {st }}$ century. These conditions have also been kept on through the aspects of so much reflected sovereignty of the national states (i.e. on the Westphalian political concept of states reputedly as subjects to the international law), however, in our reality such a concept has not had its worldwide jurisdiction constituted in present day practice, so far (Hrubec 2011, 398-399).

Besides, sovereign realm of a national state also serves as a protection against power hungry (national) hegemons of neo-colonial type who craves for influence on various areas of current societies' lives. Although it is quite obvious that the ancient concept of managing the societies as such (with all the power structure hierarchies) has, as a matter of fact, been changed rather slightly, not much of a common will for progress can be seen in this respect at present, anyway. In our reality we should actually appreciate, especially, the aspects like the roll of social elites who, of course, can no longer afford to use the same kind of straightforward ruling tactics and directives as well as the same level of oppression and direct 
torture towards their mass subjects as it used to be very common back in history of our (terrestrial) human world (Robinson 2008, 385-387).

Despite plentiful demands as well as enormous need for keeping or re-establishing social stability in many countries all over the world, it should not, as far as possible, require reintroducing any authoritarian figures or even hegemonic tyrants of the past. The job could possibly be carried out by a global roof-like associative organisation that would help with the necessary technical and material backing for its members, including the offer of a certain ideological framework that would have to be based exclusively on cosmopolitan-like ethical ideas. So, the political and administrative supervision done by the global governing body on behalf of the newly established statehood-like entities may achieve peace for a social life relatively soon in comparison with all the previous, for which case such administrative statehood entities would be provided with all the necessary resources for (re)building (post-tribal) societies on the local and regional level of geo-political governance (Held 1999, 74-75).

Such statehood political entities have been emerging elsewhere; in fact, outside of the actually outdated Westphalian concept of national states that probably already needs some transformation as well as reforms in the area of the international law. In order to lose neither peace worldwide, nor the contingency for political progress in some parts of the world, it is practical to start preparing new concepts of the global settings which would allow for political consensus that could be found more quickly in case of smaller (i.e. almost homogenic) administrative units than on the so called national level. As there is still an adverse side to all the post-World War 2 era with its strong emancipative and modernising trends, it means that to tackle this category of problems, it would, beyond any doubt, require more historical time with the use of intercultural dialog (i.e. poly$\log$ ) and traditional diplomacy for material and societal development within the Westphal-like frame of relations, especially in the area of establishing tradition of sustainable political regimes also in societies with vast range of basic existential difficulties.

The plans for the protective global governance should be similar to the concept of Commonwealth, unlike the colonial era, not on the purpose of private exploitation of any kind, but rather with cosmopolitan and humanitarian goals on the ground of communitarian principles. Nowadays, it becomes more and more obvious that in the world of information media and global websites, where the trends of humanism and decolonization have been more and more important, some of the principal hegemons of power must use more clandestine strategies to reach their goals or even surrender some privileges. However, it seems that a simple departure from the traditional tactics and patterns of influence does not necessarily have to bring expected relief into all related dimensions of the global reality under the conditions of the present neo-liberal world. Trends and rela- 
tions as such project into the areas of national economies, then the controlseeking freaks in political power must also pay attention to the economic stability, because it has an immense effect on their retaining a hold of power over the controlled territories if sometimes the ideological opposition adheres to a more extremists' attitudes and actions to achieve its plans (Fraser 2007, 130-139).

Therefore, it is necessary to create as well as to apply a conception of equality in order to deliver at least some of the promoted ideals of societal progress on short scale of time, which should eventually allow for reaching even the more extended goals, both on the international level as well as on the individual level of intersubjective relations in the strife for discursive recognition. Understandably, it is possible to achieve it only under the condition of mutual trust that would have to be arranged for with a sort of multi-level safety guaranteed. In addition to that, it should be done in the way of self-sustaining scheme which should be derived from historically conditioned paradigms, since the historical development is in its substance relatively unyielding, but it may be said that it is at least, up to a certain point, not quite hopeless endeavour, though except others in complex perspective (Hrubec 2012, 183-186).

A. Ferrara, in his very work, also speaks about secularism on the background of comparison in the area of faith between the medieval times and the present day relations. The point is that the faith in this comparison is not the same at all, because at the Mid Ages it used to be common to accept a faith without an alternative of choice unlike at present when it is, in some countries, accepted as one of the possibilities, how to devote one's soul to a course of life. So, the present day substitutes for the medieval, mainly religious, value anchoring of one's personality are just the modern urban style of life and the so called - sophisticated set of consumer's status oriented propositions, especially in the developed countries or in the large modernising urbanistic agglomerations. Those trends (viewed globally) in their contextual outcomes have certainly been laying down foundations for authentic popularization of secularism in many societies, however it depends whether there is enough of historical time to entirely rely on these trends only (Ferrara 2014, 68-70).

When the author says: "Empirical research in the sociology of religion reminds us that even the fact that people attend religious services less frequently does not mean that their lives are less shaped by religious ideas" - is it necessarily about religious ideas or rather about realization of specific ways of living which stand under influence of a particular era's living conditions and regional traditions of life? Nevertheless, the mentioned social institutions put up administrative structures as well as a row of alternatives to that subjective experience which in a conventional conformist way become a substantial factor in preventing antiestablishment critique or similarly bad moods in a society itself (Ferrara 2014, 69). 
The present world of complex societies with their administrative schemes of power structures, and popular culture trends with an undisputed influence through the social and information media, has been creating so robust a platform of cultural traditions that in combination with nationalism, can substantially make up the social construct of a society, which in return has been felt as a barrier against aliens-like intrusions into a society. So, in result of that, individuals that are supposed to be inclusively incorporated into the texture of society remain actually outside in spite of the fact that they were born into the society too. These aspects subsequently bring the individuals about to feel repudiated into the religious embracement in which, almost unmistakably, the sense of belonging is nearly always delivered and that is in fact what such excluded individuals were often so longing for (Sartori 2005, 68-73).

Then, it is common to speak about the so called self-bred social pathology that is maybe slowly, but quite steadily in quiet growth, especially in the Western world. After exhorting some efforts it may start uncovering a bit, no matter that maybe it is not meant to be revealing yet. All this offers, as a matter of fact, a clear explanation, although not always a welcomed one, as e.g. the contemporary fight against disregard illustrated like an extension of the modern trends initiating emancipation as such. These trends, as it becomes more and more obvious, show that it is basically about trying to find a proper refuge in the sense of communal belonging as well as the endogenous desire for nothing less than equality and justice, universally, for all (Hrubec 2012, 96-97).

And to explain further, it can be added that yet, since the connection between the theory and practice is still rather loose, we can be quite sure to meet with the same kind of problems over and over again, to put it in expressive way. After all, it is possible to say that until an adequate tackling of the newly arising social phenomena is practically available, the trends are, from the point of view of the subversive, to increase popularity and consequently generate not only regional insurgence. But in this case, it is proper to debate about instigating a sort of revolt on the international level, as a protest against the heritage of conservative structures (i.e. cast-system) as well as a manifestation of their endogenous cosmopolitism, which is the only global system that can uphold the ideals of equality and justice without which there is no peace to count on, but which means no easy way towards future either.

Then, as always in history of the humankind, the so called post-colonial modernisation can follow the strife for social, cultural as well as political (i.e. national) emancipation that will yet upgrade the needed quality of protection for the power grasping elites. The livelihood of the upper-classes (in wider meaning) actually depends on these efforts in order to sufficiently preserve the societal structures (i.e. cast-system, etc.) virtually of the neo-slavery totality - as it seems quite clear for some observers that the background on which any reforms and democratic 
values have been upheld with just ever more sophisticated enhancement on the point of the so called equality (at least in a time until war-like conditions defuse the social and political tension).

All of the author's variants of pluralism, no doubt, are in theory quite interesting and well grounded, nevertheless from a practical point of view the opinion may go otherwise though. In reality the practice actually rather requires a combination of the proposed variants with a sort of generalizing complex-like approach, which could do the job provided that a social and political sensibility as well as flexibility was not the stranger in the play of history. To be more particular now, it seems that within the diction of the book, secularism is quite needed to start to think about pluralism in the current world, even though at present there are societies which are not so secular, or rather, are not secular at all (Ferrara 2014, 88).

"The increased cultural pluralism of constituencies, typical of societies where migratory fluxes combine with a public culture receptive to openness and the value of diversity, which renders consensus on political values and constitutional essentials more unstable and difficult to reach relative to societies that are either more impermeable to immigration or more inclined to accept the public hegemony of the culture of the majority - a condition of hyperpluralism with which a renewed version of political liberalism will have to come to terms in ways explored..." (Ferrara 2014, 7).

To conclude, it is possible to express that "maybe when the gradual negation of Liberalism allows to achieve more of the global justice as fairness, then even the Multiculturalism won't come short, which actually means that both, on the social (i.e. national) as well as planetary level, could find a kind of revival. However, is it sensible at all to think of anything else than of a completion of Liberalism in our set of logic?" Would it mean in the author's assessment that the less secular societies are, as a matter of fact, the higher is the potential for a critical collision of civilizations? Since these societies' social construct of immanent frame would probably indicate a form of totality in which case there would only be a little left to count on, as for the historical context of international affairs provided that any discrimination, or even genocide, ought to be avoided. Well, I would then suggest that the job could be done just by the institution called "global state", because it is something that would fill up the so called "empty space" or vacuum, especially in the areas of the political and administrative duties as well as cultural and societal aspects, so needed especially for instigating the radicalization of Islam, or others of its kind. 


\section{References}

FRASER, N. (2007): Rozvíjení radikální imaginace. Globální prèerozdělování, uznání a reprezentace. Praha: Filosofia.

HELD, D. (1999): Global Transformations. Politics, Economics and Culture. Cambridge: Polity Press.

HRUBEC, M. (2011): Od zneuznání ke spravedlnosti: Kritická teorie globální společnosti a politiky. Praha: Filosofia.

HRUBEC, M. a kol. (2012): Etika sociálních konfliktů. Axel Honneth a kritická teorie uznání. Praha: Filosofia.

ROBINSON, W. I. (2008): Překonávání teorie imperialismu: globální kapitalismus a nadnárodní stát. In: Hrubec, M. (ed.): Sociální kritika v ére globalizace. Odstraňování sociálně-ekonomických nerovností a konfliktů. Praha: Filosofia, 385-413.

SARTORI, G. (2005): Pluralismus, multikulturalismus a přistěhovalci. Esej o multietnické společnosti. Praha: Dokořán.

SCHEUERMAN, W. E. (2011): The Realist Case for Global Reform. Cambridge: Polity Press.

SKLAIR, L. (2000): The Transnational Capitalist Class. London: Blackwell.

SUŠA, O. (2010): Globalizace v sociálních souvislostech současnosti. Diagnóza a analýza. Praha: Filosofia.

\section{Mgr. Mikuláš Havran}

Department of Political science

Faculty of Arts

Charles University

Nám. J.Palacha 2

11638 Praha 1

Czech Republic

m.havran@tiscali.cz 